\title{
Assessment of Heavy Metal Species in Some Decomposed Municipal Solid Wastes in Bida, Niger State, Nigeria
}

\author{
Usman Idris Nda-Umar ${ }^{1}$, Gobi Samuel Nathaniel ${ }^{1}$, Abdullahi Mann ${ }^{2, *}$, Jonathan Yisa ${ }^{2}$ \\ ${ }^{1}$ Department of Science Laboratory Technology, School of Applied Arts and Science, \\ The Federal Polytechnic, Bida, P.M.B. 55, Bida, Niger State, Nigeria \\ ${ }^{2}$ Department of Chemistry, Federal University Technology, Minna, P. M. B. 65, Niger State, Nigeria
}

\begin{abstract}
Soil samples collected from three decomposed municipal solid waste dump sites located in Esso, Gbangbara and Eyagi areas of Bida town were analyzed for some heavy metals $(\mathrm{Cu}, \mathrm{Fe}, \mathrm{Pb}, \mathrm{Mn}$ and $\mathrm{Cr})$, using Atomic Absorption Spectrometer. The analysis of the aqua regia digestion showed an average mean concentration $(\mathrm{mg} / \mathrm{kg})$ of $\mathrm{Cu}(342.22 \pm 7.6), \mathrm{Mn}$ $(570.00 \pm 1.0)$ and $\mathrm{Fe}(371.11 \pm 1.2)$ in the three dump sites were exceptionally high. The variation of these heavy metals across these three dump sites were in the order $\mathrm{Pb}(\mathrm{EY})>\mathrm{Pb}(\mathrm{ES})>\mathrm{Pb}(\mathrm{GB}), \mathrm{Mn}(\mathrm{GB})>\mathrm{Mn}(\mathrm{ES})>\mathrm{Mn}(\mathrm{EY}), \mathrm{Fe}(\mathrm{GB})>\mathrm{Fe}(\mathrm{GB})>$ $\mathrm{Fe}(\mathrm{ES})>\mathrm{Fe}(\mathrm{EY}), \mathrm{Cr}(\mathrm{GB})>\mathrm{Cr}(\mathrm{EY})>(\mathrm{ES}), \mathrm{Cu}(\mathrm{GB})>\mathrm{Cu}(\mathrm{ES})>\mathrm{Cu}(\mathrm{EY})$. The analysis of the weak sodium acetate solution digestion showed that $\mathrm{Cu}(5.47 \pm 0.2), \mathrm{Mn}(1.88 \pm 0.0)$ and $\mathrm{Fe}(1.47 \pm 0.1)(\mathrm{mg} / \mathrm{l})$ on the average exhibited high concentrations in the dump sites. Most of the $\mathrm{Cu}, \mathrm{Mn}$ and $\mathrm{Fe}$ were found to be associated with the exchangeable fraction, which is very soluble and mobile. Base on Federal Environmental Protection Agency and Land Disposal Restrictions standard regulations, these metals exhibit hazardous concentrations.
\end{abstract}

Keywords Commercial Activity, Heavy Metals, Bida, Municipal Solid Waste

\section{Introduction}

Municipal solid waste also called urban solid waste is waste type that includes predominantly house hold waste (domestic waste) with sometimes the addition of commercial waste by a municipality within a given area. They are either in solid or semi solid form and generally exclude industrial hazardous wastes[1]. Decomposed municipal solid waste is a waste type that has been accumulated in a dump site over a long period of time and the dump site has been allowed for the reformation of the soil[1].

The environmental impact of solid waste, sewage sludge and contaminated sediments are greatly influenced by their heavy metal content. Assessment of the species of heavy metals enables the evaluation of the metal bioavailability and the determination of the suitability of the decomposed waste as compost or cover material. Speciation is the study of different chemical forms of metal ions present in environmental samples. The chemical form of the metal controls the bioavailability or mobility. The exchangeable and acid extractable fractions are mobile fractions that are easily bioavailabile. The oxidizable and reducible form will be leach out only under extreme conditions while the residual fraction is almost inert towards bioavailability[2].

* Corresponding author:

abdumann@yahoo.com (Abdullahi Mann)

Published online at http://journal.sapub.org/aac

Copyright (C) 2012 Scientific \& Academic Publishing. All Rights Reserved
Heavy metals are among the hazardous pollutant of our environment. Heavy metal contamination can affect soil ecosystem sufficiently to result in significant loses of soil quality evidence by their toxicity to processes catalyzed by soil microorganisms[3]. Heavy metals are non-degradable hence are not readily detoxified and removed by metabolic activities once present in the environment. This source of heavy metals has to do with human activities such as exhaust from automobile fuels and industrial activities such as production of dental amalgam, paints, thermometers, soldering materials, batteries, cable coverings, ammunitions, pencils, plastics, x-ray shielding, crystal glass production and thinners[4]. Agricultural activities that release some heavy metals into the environment are the use of pesticides and fertilizers[5]. Apart from agricultural activities, sewage disposal pollutants enter into water bodies from urban areas. Most of these sewage effluents contain some heavy metals. This is due to the fact that some toiletries contain little amount of these heavy metals as antimicrobial agents[6]. Heavy metals become toxic in human when they are not metabolized by the body and accumulate in the soft tissues. Heavy metal may enter the human body through food, water, air, cosmetics or absorption through the skin when they come in contact with humans. Industrial exposure accounts for a common route of exposure in children[7]. Children may develop toxic level from the normal hand-to-mouth activity of small children who come in contact with contaminated soil or by actually eating objects that are not food (diet or plant chips)[8].

Therefore, there is a great need for routine analysis of soils 
from industrial, agriculture, decomposed solid waste and dump sites in order to assess the availability and level of these toxic metals[9]. This research work is to determine heavy metal species in decomposed municipal solid waste collected from Esso, Gbangbara and Eyagi dump sites in Bida town of Nigeria.

\section{Materials and Methods}

\subsection{Sample Collection}

The soil samples were collected in June, 2009 from decomposed municipal solid waste dump sites located in Esso, Gbangbara and Eyagi areas of Bida town which represent areas with high population density associated with increased commercial activities and high refuse disposal rate (domestic, metal scraps, heavy metals parts etc). The soil samples were collected from the center of the sites. All samples were collected the same day and kept in a labeled polythene bags.

\subsection{Preparation of Standard}

Stock solutions of chromium, copper, iron, manganese and lead were prepared in accordance with standard methods [10].

\subsection{Sample Preparation}

The soil sample collected from the three dump sites were air- dried in the laboratory and grinded separately into fine size using a mortar and pistil and sieved using $1.0 \mathrm{~mm}$ mesh.

\subsection{Digestion of Sample}

$1 \mathrm{~g}$ of sieved air dried soil sample was weighed in a hard glass digestion tube. $20 \mathrm{ml}$ of the digestion acid was added and the flask was fixed in a clamp and kept overnight. The temperature of the hot plate was increased from $180-200^{\circ} \mathrm{C}$ when the initial reaction had subsided. This digestion was then continued with occasional swirling until there was no visible particle and digestion acid was quite cleared. The flask was then removed from the heating source and allowed to cool before it was transferred by filtering into $100 \mathrm{ml}$ capacity volumetric flask and made up to the standard mark with deionized water. This was then transferred into washed polythene bottle and kept in dust proof glass chamber ready for analysis.

\subsection{Sample Analysis}

The qualitative analyses of the samples were carried out using Buck Scientific Atomic Absorption (Model 210 GP) with air acetylene flame. Samples were aspirated into the flame, the heavy metal of interest present in the sample absorbed some of the light from the hollow cathode lamp reducing the intensity of the light transmitted. The computer data system of the machine converted the intensity of light into the absorbance which was directly proportional to the concentration of the heavy metals present in the sample. The concentration of the heavy metals present was determine from the working curve after calibrating the instrument with standard of all the heavy metals to be analyzed. In order to ensure accuracy, triplicate determinations were made for each of the sample collected from the three locations. The result obtained was then subjected to statistical analysis.

\section{Results and Discussion}

The result of some selected heavy metals analyzed in decomposed municipal solid wastes collected from Esso, Gbangbara, and Eyagi dump sites in Bida town using aqua regia digestion is present in Table 1 . The result of the toxicity characteristic leaching using weak sodium acetate solution is presented in Table 2.

Table 1. Result of some selected heavy metals in Esso, Gbangbara and Eyagi dump sites

\begin{tabular}{|c|c|c|c|c|c|}
\hline \multicolumn{5}{|c|}{ Mean concentration of heavy metals (mg/kg) } \\
\hline Sample/ location & $\mathrm{Pb}$ & $\mathrm{Mn}$ & $\mathrm{Fe}$ & $\mathrm{Cr}$ & $\mathrm{Cu}$ \\
\hline $\mathrm{ES}$ & $126.67 \pm 0.6$ & $573.33 \pm 0.6$ & $433.3 \pm 1.2$ & $\mathrm{ND}$ & $366.67 \pm 1.2$ \\
\hline $\mathrm{GB}$ & $\mathrm{ND}$ & $640.00 \pm 1.2$ & $606.67 \pm 1.2$ & $286.67 \pm 1.2$ & $366.67 \pm 1.2$ \\
\hline EY & $176.67 \pm 1.2$ & $496.67 \pm 1.2$ & $573.33 \pm 1.2$ & $130.66 \pm 0.6$ & $293.33 \pm 0.6$ \\
\hline Mean & $101.11 \pm 0.0$ & $570.00 \pm 1.0$ & $371.11 \pm 1.2$ & $139.11 \pm 0.6$ & $342.22 \pm 7.6$ \\
\hline
\end{tabular}

Key: Mean \pm Standard deviation of three determinations, ND = Not detected, ES = Esso dump site, GB = Gbangbara dump site, EY = Eyagi dump site

Table 2. Data of selected heavy in Esso, Gbangbara and Eyagi dump sites in Bida town

\begin{tabular}{|c|c|c|c|c|c|}
\hline \multicolumn{6}{|c|}{ Mean concentration of heavy metals (mg/l) } \\
\hline Sample/ location & $\mathrm{Pb}$ & $\mathrm{Mn}$ & $\mathrm{Fe}$ & $\mathrm{Cr}$ & $\mathrm{Cu}$ \\
\hline ES & $0.79 \pm 0.02$ & $2.00 \pm 0.01$ & $1.45 \pm 0.01$ & ND & $0.50 \pm 0.32$ \\
\hline GB & ND & $2.52 \pm 0.02$ & $1.92 \pm 0.02$ & $2.49 \pm 0.02$ & $6.50 \pm 0.02$ \\
\hline EY & $0.75 \pm 0.02$ & $0.13 \pm 0.02$ & $1.03 \pm 0.02$ & $0.72 \pm 0.01$ & $4.40 \pm 0.01$ \\
\hline Mean & $0.51 \pm 0.01$ & $1.88 \pm 0.01$ & $1.47 \pm 0.01$ & $1.07 \pm 0.01$ & $5.47 \pm 0.12$ \\
\hline
\end{tabular}

Key: Mean \pm Standard deviation of three determinations, ND = Not detected, ES = Esso dump site,GB = Gbangbara dump site, EY = Eyagi dump site 
Table 1 show the mean concentrations and standard deviations of some heavy metals analyzed in soil samples from Esso, Gbangbara, and Eyagi dump sites respectively. On the average, the mean concentration $(\mathrm{mg} / \mathrm{Kg})$ of copper (342.22 \pm 7.6$), \mathrm{Mn}(570.00 \pm 1.0)$, and $\mathrm{Fe}(371.11 \pm 1.2)$ are exceptionally high. Similar observations have been reported on Bode-osi dump site[11] and some selected dump site in Ado-Ekiti metropolis[12]. Also, a similar trend was observed in forage samples from Landzu, Musa and Umar Rivers in Bida town [13]. Table 1 also revealed the variation in the mean concentration of the heavy metals across the three dump sites. The variation of these heavy metals across the three dump sites was in the order $\mathrm{Pb}(\mathrm{EY})>\mathrm{Pb}(\mathrm{ES})>\mathrm{Pb}$ (GB); $\mathrm{Mn}(\mathrm{GB})>\mathrm{Mn}(\mathrm{ES})>\mathrm{Mn}(\mathrm{EY}), \mathrm{Fe}(\mathrm{GB})>\mathrm{Fe}(\mathrm{ES})>$ $\mathrm{Fe}(\mathrm{EY}), \mathrm{Cr}(\mathrm{GB})>\mathrm{Cr}(\mathrm{EY})>\mathrm{Cr}(\mathrm{ES})$ and $\mathrm{Cu}(\mathrm{GB})>\mathrm{Cu}$ $(\mathrm{ES})>\mathrm{Cu}(\mathrm{EY})$.

Based on the result of aqua regia digestion, $\mathrm{Mn}$ exhibited the highest concentration followed by $\mathrm{Fe}$ and $\mathrm{Cu}$ in all the three dump sites. This is because the dump sites are enriched with $\mathrm{Mn}, \mathrm{Fe}$, and $\mathrm{Cu}$ through the deposition of used dry cells and batteries, used metals, some scrabbled cooking utensils, coils and alloys respectively. The high concentration of $\mathrm{Pb}$ in Eyagi dump site and $\mathrm{Mn}$ in Gbangbara dump site is due to large deposits of used batteries, accumulators, used plastics materials as well as used lubrication oils. While the high concentration of $\mathrm{Cu}$ and $\mathrm{Fe}$ in Gbangbara dump site is due to the activities of welders-melting cast and brass for welding metals. Wastes from these workshops are deposited on this dump sites thereby enriching these dump sites with $\mathrm{Fe}, \mathrm{Cu}$ and other metals respectively. Table 2 shows that $\mathrm{Cu}$ $(5.47 \pm 0.12) \mathrm{mg} / \mathrm{l} \mathrm{Mn}(1.88 \pm 0.01) \mathrm{mg} / \mathrm{l}$ and $\mathrm{Fe}(1.47 \pm 0.01)$ $\mathrm{mg} / \mathrm{l}$, on the average exhibited high concentration in all the dump sites. From the Table $2 ; \mathrm{Pb}, \mathrm{Cr}, \mathrm{Cu}$, and $\mathrm{Mn}$ on the average exhibited hazardous concentrations base on the regulations[1,14], while Fe exhibited a concentration below hazardous level in all the three dump sites. Similar observation has been reported on Henchir El Yahaudis dump site in Yuri city[15]. The high concentration of these selected heavy metals as presented in Table 2 is an indication that there is high occurrence of the exchangeable species of these metals in the three dump sites than the acid extractable species. This also indicates toxicity risk since the exchangeable species are readily soluble in water. According to the result of the aqua regia digestion presented in Table 1 and the result of the toxicity characteristic leaching procedure presented in Table 2 , these dump sites are pollution sources of potential toxic metals to the surrounding environment; since the metals will be eventually washed by erosion into adjoining wells[15]. In addition to this, farmers rely on the biodegraded dump for compositing not minding the effect of such an awful cost cutting techniques.

\section{Conclusions}

The concentration of the selected heavy metals in decomposed municipal solid wastes collected from Esso,
Gbangbara, and Eyagi Dump sites were analyzed using aqua regia digestion and weak sodium acetate solution extraction. The aqua regia extraction result revealed that $\mathrm{Pb}, \mathrm{Mn}, \mathrm{Fe}, \mathrm{Cr}$, $\mathrm{Cu}$ exhibited high concentration above the regulated values of FEPA. The weak sodium acetate solution extraction results indicated that $\mathrm{Mn}, \mathrm{Cr}$, and $\mathrm{Cu}$ exhibited hazardous levels base on FEPA's regulations and the land disposal restrictions. Base on the results of this research work, it is concluded that these dump sites are sources of heavy metals pollution and toxicity to the surrounding environments.

\section{Recommendation}

Based on the result of this research work, it is recommended that the Federal Environmental Protection Agency should provide dustbins at strategic places within the municipalities as well as provide refuse incineration and treatment plants to check indiscriminate refuse dumping. The populace should be discouraged from indiscriminate use of decomposed solid wastes for agricultural purpose.

\section{REFERENCES}

[1] USEPA 2002, Municipal solid waste. (Assessed 04-03-09). Available at http://w ww.USEPA/ munipalwaste/ publication.net

[2] Sebathian, E., Ammaiyppan, S., Kuria, J., and Kanda Samy P., 2005, Assessment of heavy metal species in decomposed municipal solid waste (Assessed 04-05-09). Available at http://www.setlet.com

[3] J.W. More, Environmental Chemistry $2^{\text {nd }}$ Ed. Academy Press New York. pp 118, 393-397, 1976

[4] Brown, D.J. 1998. Characterizing Risk at Metal Finishing Facilities. Meeting the Needs of all Stakeholders. Office of Research and Development. EPA/600/R-97/111, May 1998.

[5] R.A. Goyer, Toxic Effective of Metals; Mercury. Case rett and doull's Toxicology. The Basic Science of poisons, Fifth Edition 1996. New York. Mc Gram-hill. pp 1084-1088, 1999

[6] Ferner, D.J. 2001, Toxicity and Heavy metals. eMedicine Journal, 2 (5):1

[7] Roberts, H. 1999, Lead poisoning (Accessed 01-02-09). Available online at http://www.setlet.com

[8] D. Dupler, Heavy metal poisoning. Gale Encyclopedia of Alternative medicine. Farmington Hills, Gale group. pp 2054-2057, 200

[9] EPTA, 2001, the effect of heavy metals on the environment and on health. (Accessed 07-04-09). Available online at http://wwweptanetwork.org/EPTA/projects.php

[10] C.M.A. Ademoroti, Environment chemistry and T Foludex press Ltd Ibadan. pp 180-200, 1996

[11] Amusan, A.A., Ige, D.V. and Olawale, R., 2005, Characteristics of soil and crop uptake of metals in Municipal waste 
dump sites in Nigeria. J. Human Ecol., Kamla Rja, 1(2): $167-171$

[12] Adefemi, S.O and Awokunmi, E.E., 2009, The impact of municipal solid waste Disposal in Ado-Ekiti State, Nigeria. Afr. J. Env. Sci. \& Technol., 3 (8): 186-188

[13] Idowu, S.B., 2007, Determination of Heavy metal concentration in some selected forage Grasses commonly consumed by Animals around Niger and Kwara State of Nigeria. HND Project, Department of Science Laboratory Technology (Chemistry Option). School of Applied Art and Sciences, The Federal Polytechnic Bida, Niger State, pp 15-16
[14] FEPA, 2003, Standard regulated values of some heavy metals by the Federal Environmental Protection Agency of Nigeria. J. Env. Health Res., 2(1): 37

[15] Abdoul, N.I., Mistsu, Y. and Ahmed, G., 2004, Potentially Toxic Elements Concentration in decomposed waste Residue collected from closed solid waste landfill. Proceeding of the 15th Annual conference of the Japan society of waste management Experts, 3: 23 